Federal Reserve Bank of Dallas

Globalization and Monetary Policy Institute

Working Paper No. 81

http://www.dallasfed.org/assets/documents/institute/wpapers/2011/0081.pdf

\title{
Lessons for Monetary Policy: What Should the Consensus Be? *
}

\author{
Otmar Issing \\ Center for Financial Studies \\ Goethe University Frankfurt
}

April 2011

\begin{abstract}
This paper outlines important lessons for monetary policy. In particular, the role of inflation targeting, which was much acclaimed prior to the financial crisis and since then has not lost much of its endorsement, is critically reviewed. Ignoring the relation between monetary policy and asset prices, as is the case in this monetary policy approach, can lead to financial instability. In contrast, giving, inter alia, monetary factors a role in central banks' policy decisions, as is done in the ECB's encompassing approach, helps prevent these potentially harmful side effects and thus allows for fostering financial stability. Finally, this paper makes a case against increasing the central banks' inflation target.
\end{abstract}

JEL codes: E44, E52, E58

\footnotetext{
* Otmar Issing, President, Center for Financial Studies and Chairman of the Advisory Board of the House of Finance, Goethe University Frankfurt, Grüneburgplatz 1, HPF H5, 60323, Germany. +49 (0) 69-798-30050. issing@ifk-cfs.de. This working paper formed the basis of the author's presentation at "Macroeconomic and Growth Policies in the Wake of the Crisis," a conference hosted by the IMF on March 7-8, 2011. I am grateful for valuable comments to Marcel Bluhm, Vitor Gaspar, Allan Meltzer, Athanasios Orphanides, Huw Pill, and Massimo Rostagno. I would also like to thank Marc DeFrancis and Josh Felman for editorial advice. The views in this paper are those of the author and do not necessarily reflect the views of the Federal Reserve Bank of Dallas or the Federal Reserve System.
} 


\section{$\underline{1 .}$ Consensus continues?}

Every crisis also opens an opportunity. The challenge of this crisis for policy makers and researchers is to identify which factors were decisive for all these problems and what could be done to increase our knowledge and improve policy to prevent a repetition of past mistakes and by that hopefully also the emergence of a new crisis. To be clear - the idea cannot be to avoid any ups and downs of the economy. Cyclical movements are an unavoidable and even necessary element of any dynamic economy. What must not happen is a financial crisis of the dimension just seen.

A flood of studies on "Lessons" gives the impression that research has taken up this challenge. On monetary policy a legion of papers has already been published (e.g. Bean 2010; Clarida 2010; Fahr et al. 2010; Mishkin 2010, Svensson 2009), and many more will come. A number of papers discuss issues in the broader context of general macro and/or prudential aspects (Blanchard et al 2010; IMF 2010).

Most approaches start from what is seen as the pre-crisis consensus. Whereas the details may differ the result boils down to inflation targeting as state of the art of monetary policy. And, after reflections what lessons to take from the crisis - for a thorough analysis see Mishkin (2010) - the conclusion is that this strategy is still optimal. "The case for the basic monetary policy strategy, which for want of a better name, I have called flexible inflation targeting, is still as strong as ever, and in some ways, more so” (Mishkin, 2010, p. 48). Another prominent advocate comes to this result: "In the end, my main conclusion so far from the crisis is that flexible inflation targeting, applied the right way and using all the information about financial factors that is relevant for the forecast of inflation and resource utilization at any horizon, remains the best-practice monetary policy before, during, and after the financial crisis.” (Svensson 2009, p. 7).

With all respect for highly influential research this statement immunizes the strategy against any critique. ${ }^{1}$ And stating that a strategy which fulfils these demanding conditions - "using all information” etc. -is best practice comes close to a tautology. But, beyond that this defense of

\footnotetext{
${ }^{1}$ In this context it is interesting to follow the headlines under which this approach was presented: From „inflation targeting“ to „inflation targeting with judgement“ to „flexible inflation targeting“ (see e.g. Svensson 2005). To be fair, authors representing this philosophy acknowledge now that financial factors have to be taken into account. How far is this driving flexibility?
} 
inflation targeting implies the pretension that previous versions fulfilled the principle of “using all information”. Looking back to the performance of the strategy it is hard to accept this as a convincing statement.

Most papers on "Lessons" like those mentioned start from the assumption that flaws in the strategy can be corrected by adding factors missing so far but do not put into question the concept as such. Is this not fighting the last war and risking to lose the next one, too? Would it be not more promising to start from identifying the principles of a framework which is robust through any conditions and challenges which lie in the future. This was at least our ambition at the ECB when we designed our strategy under the motto: "The need for robustness in a world of uncertainty” (ECB 2000). ${ }^{2}$

Before continuing a clarification is needed as the wide use of the term "inflation targeting" can lead to confusion. One can distinguish between (at least) three versions of inflation targeting.

1) A concept when the central bank has the objective of price stability or rather low inflation. In this respect it is hard to find a central bank which is not an "inflation targeter".

2) A strategy which comprises the following elements:

a) a quantitative definition of the overriding objective of price stability respectively low inflation,

b) a forward looking monetary policy,

c) transparency of the decision making process and corresponding communication with the public.

This definition leaves open how the central bank conducts its policy to achieve the final objective, i.e. to what extent it just relies on a traditional inflation forecast or which role is e.g. given to money and credit when deciding monetary policy. This concept is now more or less widely adopted (e.g.Walsh 2009) and in this sense also the European Central Bank might be called “inflation targeter” (Issing et al.2001; Issing 2004).

3) Inflation targeting as a theoretical concept of optimal monetary policy. The crucial element here has been and still is the link between an inflation forecast and monetary policy decisions. In the words of Svensson (2005)-which already reflect refinements of the original concept:

\footnotetext{
${ }^{2}$ It is worthwhile to quote from this early publication (p.45): “The ECB`s strategy embodies a `full information approach in a broad sense, i.e. it is a framework that not only encompasses all relevant information, but also takes into account various, possibly different interpretations of this information. Against this background, the strategy adopted by the ECB represents a framework that reduces the risks of policy errors caused by overreliance on a single indicator or model. Since it adopts a diversified approach to the interpretation of economic conditions, the ECB`s strategy may be regarded as facilitating the adoption of a robust monetary policy in an uncertain environment.”
} 
“The modern monetary policy process I have in mind can be concisely described as `forecast targeting`, meaning `setting the instrument rate such that the forecasts of the target variables look good', where 'look good refers to the objectives of monetary policy, such as a given target for inflation and a zero target for the output gap”.

This concept was widely seen as "state of the art" in research. However, overall central banks did not- at least not strictly- apply this approach.

\section{Monetary Policy and Asset Prices}

For many years most central banks agreed that monetary policy should take asset price developments into account only to the extent that they might have an effect on spending via wealth effects and thereby on the outlook for inflation. ${ }^{3}$ This prevailing orthodoxy embraced what I have called the “Jackson Hole Consensus” as it was prominently presented several times at this conference (Greenspan 2002; Blinder/Reis 2005; see also Mishkin 2007):

1. Central banks should not target asset prices.

2. Central banks should not try to prick a bubble.

3. Central banks should follow a "mop up strategy" after the burst of a bubble which means injecting enough liquidity to avoid a macroeconomic meltdown.

There can hardly be any disagreement on these principles. A central bank has no instruments to target successfully individual asset prices and creating a macroeconomic mess by pricking a bubble would ruin the reputation of a central bank. And, not least the monetary policy mistakes after 1929 (as documented by Friedman/Schwartz 1963) are ample evidence for advising central banks to take all necessary steps to avoid as far as possible the propagation of the consequences of a collapse of asset prices through the financial sector to the real economy (Issing 2009).

However, restricting the role of the central bank to be totally passive in the period of the build-up of a bubble and practically pre-announcing its function as a "saviour" once a bubble bursts represents an asymmetric approach which might create moral hazard and over time contribute to if not trigger a sequence of ever larger bubbles and following collapses.

\footnotetext{
${ }^{3}$ Which by the way implies a great challenge as to the time horizon of the inflation forecast.
} 
In this context it is interesting to read the following interpretation (Blinder/Reis 2005, p. 6768):

“The 'mop up after' strategy received a severe real world stress test in 2000-2002, when the biggest bubble in history imploded, vaporizing some $\$ 8$ trillion in wealth in the process. It is noteworthy, but insufficiently noted, that the ensuing recession was tiny and that not a single sizable bank failed. In fact, and even more amazing, not a single sizable brokerage or investment bank failed either. Thus the fears that the 'mop up after' strategy might be overwhelmed by the speed and magnitude of the bursting of a giant bubble proved to be unfounded. Regarding Greenspan's legacy, then, we pose a simple rhetorical question. If the mopping up strategy worked this well after the mega-bubble burst in 2000, shouldn't we assume that it will also work well after other, presumably smaller, bubbles burst in the future? Our suggested answer is apparent”.

As we know today what followed was another bubble and subsequent collapse of a much larger dimension. ${ }^{4}$ It should be obvious that the "Consensus" has a problem. Mishkin (2010) sees a consequence in arguing in favour of aggressive actions by central banks in case of financial disruptions. However, this is only extending the asymmetry in the so called risk management approach which was advocated by Greenspan (2005). One might ask if this concept should be applied at all in monetary policy (for a critique see Buiter 2008). However, risk management as a strategy to deal with low probability events and severe outcomes should by construction be neutral towards upside and downward risks. This would imply that the cost-benefit-analysis should not just consider the consequences of a potential burst of a bubble, but also be applied for estimating the risks implied in an emerging bubble and the costs and benefits of trying to prevent this (see White 2009). Seen from this perspective the foremost challenge would be to prevent the development of a huge bubble rather than to concentrate on what should be done once a bubble bursts. Should this not be the most important message coming from all major macroeconomic disasters in history which were triggered by a burst of a preceding bubble? The question what to do once a bubble bursts remains, but should come only second in case the evolution of a major bubble in spite of all efforts could not have been prevented.

Inflation targeting (version three in the above clarification) is paradigmatic here: an inflation targeting central bank only needs to concentrate on one indicator, the inflation forecast, and

\footnotetext{
${ }^{4}$ White (2009) traces back the cumulative effects of "pre-emptive easing“ to the stock market crash of 1987.
} 
on one objective, inflation, which summarise all the policy-relevant information. But, an inflation decline which is due to a fall in demand is a very different macroeconomic phenomenon than a decline in inflation that originates on the supply side.(The same logic applies to the case of an increase in inflation.) For an inflation targeting central bank, a decline in inflation does not need further qualifications.

Such a situation makes monetary policy extremely sensitive and averse to disinflation and, ultimately, turns policy into an independent source of instability, particularly in an environment characterised by a prevalence of positive supply-side shocks (like in the second half of the 1990s). In such an environment there is a risk that policy forbearance vis-à-vis disinflationary forces fuels financial exuberance and financial exuberance in turn creates financial imbalances.

This raises two questions:

1. Can the emergence of a major bubble be identified?

2. What instruments are available to avoid the realization of a major bubble?

1) The uniform answer for a long time was that central banks cannot identify a bubble in real time. This was often connected with reference to the efficient market hypothesis according to which market prices incorporate all relevant information. How could central banks pretend to know better?

The recent crisis has led to a renewal of the discussion about the validity of the efficient market hypothesis. Central banks can deal with this uncertainty by looking at information beyond prices, notably financial quantities and flows (see ECB 2010a). The challenge for central banks is not to assess if specific assets were properly valued. What matters for central banks is the development of stock prices or housing prices in general. And here a number of tools were always available and methods have been refined to identify misalignments of asset prices (see e.g. ECB 2010a).

2) An often repeated argument that central banks should not lean against the emergence of a bubble (Kohn 2007 in a succinct presentation calls it "extra action") is that the only instrument available is the interest rate which -following the Tinbergen Rule- cannot be used for two (or more) purposes. To mitigate upward developments of asset prices strong increases 
in the central bank interest rate would be needed which would imply major - and in essence too high - macroeconomic costs in form of losses in output and employment. However, this argument is far less convincing than it seems. Taylor (2007) presents a "counterfactual" exercise for how the Fed could have moderated house price developments by a timely increase in interest rates. (For a different approach see Orphanides/Wieland 2008.)

New research and empirical evidence have delivered further arguments in favour of the potential effectiveness of using the central bank interest rate to stabilize financial markets (Papademos 2009).

1) Even small changes in the spread between long- and short-term interest rates might have a substantial effect on the profitability of financial actors with high leverage and maturity mismatch problems. For the effectiveness of such actions it is important that they are taken at an early stage before "irrational exuberance" can take hold. As the central bank can influence the yield curve it would contribute to curtailing maturity mismatch and leverage (Adrian/Shin 2009).

2) Communication about evolving imbalances combined with relatively small changes in the key policy rate could serve as a signalling device and support the credibility of the risk assessment of the central bank (Hoerova/Monnet/Temzelides 2009).

3) Finally, even a moderate increase at an early stage of an asset price boom - in combination with the first two factors - could work against herding behaviour.

These are strong arguments in favour of "leaning" - i.e. against the wind of asset price booms - and against (only) “cleaning” - i.e. following the asymmetric approach described (White 2009).

However, this is not an argument that the whole responsibility should be left to monetary policy. Quite a number of other tools mainly of a regulatory nature to preserve financial stability are already disposable or should be developed (e.g. Bank of England 2009). Depending on the institutional arrangement these instruments are either in the hand of the central bank itself or lie with another institution which makes good cooperation indispensable. The question to what extent there might be a conflict between maintaining price stability and preserving financial stability has now become a major topic for discussions (for an early 
contribution see Issing 2003). Macroprudential supervision is now being established almost everywhere and it will be interesting to observe the working of the new European Systemic Risk Board. It will be fundamental that identification of macroeconomic risks should not create pressure on the monetary policy of the ECB and necessary actions are taken by the supervisory authorities.

\section{The Role of Money and Credit}

Progress in economic research is not linear. Economic theory develops in cycles - one might even sometimes speak of fashions - even with loops (Issing 2010).

It is no exaggeration to say that "money" - in a very broad sense - over many years was widely ignored in mainstream economics. To a large extent this was also the case in central banks. Overall, the fundamental argument was that for reasons of financial innovations etc. the historical relation between "money", nominal GDP growth, and inflation had broken down - velocity had become unpredictably volatile. ${ }^{5}$

This verdict on "money" in the first place refers to the relation between a monetary aggregate and inflation etc. However, the neglect extended to monetary factors in general including the composition of monetary aggregates and their counterparts which is above all credit.

Now the tide seems to turn. Interestingly it is the financial crisis which has triggered considerations if asset price booms caused by credit expansion should not be a matter of concern (Blinder 2010; Mishkin 2010). There should have been ample evidence before the crisis that money and especially credit can be a driving factor of asset prices. ${ }^{6}$ Research by the BIS (e.g. Borio/ Lowe 2002; Borio/ Lowe 2004) and the ECB (e.g. Detken/Smets 2004) supports the view that hardly any major unsustainable boom in asset prices was not accompanied if not preceded by strong increases in credit and/or money. Monetary factors- I use this term in a broad sense including credit in all its manifestations- can be used for the analysis of ongoing asset price developments as well as for forecasting those developments (ECB 2010 a, ECB 2010 b; Gerdesmeier et al. 2009). A central bank which monitors the

\footnotetext{
${ }^{5}$ However, Meltzer (2009) shows that using annual data deliver a stable relationship for the US. See also Lucas (2007).

${ }^{6}$ For an interesting "loop“ in research on the relation between large movements in money and credit and boom bust cycles in asset price see Fisher (1932) or Hayek (1933).
} 
development of money and credit and takes these factors into account when making monetary policy decisions therefore implicitly applies a "leaning against the wind strategy" without having to identify the emergence of bubbles (or the opposite).

In a world of globalised financial markets "domestic" money and credit and therefore asset prices (as well as domestic inflation) might be influenced by global developments. This aspect has been studied by a number of papers (e.g. Sousa/Zaghini 2004; Borio/Filardo 2007; Rüffer/Stracca 2007; Alessi/Detken; Ciccarelli/Mojon 2010). This leads to the question what a central bank can achieve acting alone, respectively what would be then the consequence for the exchange rate.

As already discussed notwithstanding the fact that macroprudential tools should play a major role the challenge for monetary policy is how to integrate asset price considerations - i.e. "leaning against the wind" - into the monetary policy strategy. For inflation targeting this seems very hard to do. Inflation targeting with all its refinement is based on a forecast for (goods price) inflation using models in which monetary factors do not play an active role. Including "frictions" in such models might be useful as a research strategy, but cannot give practical advice to monetary policy makers (see e.g. Curdia and Woodford, 2010). Svensson (2009, p. 7) makes a rather sober statement: "Before such extensions of the modelling framework are operational policymakers and staff have to improvise and apply unusual amounts of judgement on the effects of the financial crisis on the transmission mechanism. Even with much better analytical foundations concerning the role of financial factors in the transmission mechanism, there will be of course, as always, considerable scope for the application of good judgement in monetary policy.”

This “confession” raises fundamental questions on appropriate communication, on the predictability and credibility of the central bank, and finally on anchoring inflation expectations. Is it unfair to say that what was once seen as the "beauty" of an approach connecting monetary policy decisions with the forecast of inflation seems now to be more or less dissolved?

The fundamental problem of inflation targeting becomes obvious in a situation in which the forecast for (goods price) inflation signals "no need to change central bank interest rates" - or might even indicate downward risks - whereas credit (and money) are rising together with 
asset prices increases. The "risk taking channel" (Borio/Zhu 2008; Adrian/Shin 2009) explains how low interest rates foster the emergence of financial imbalances and create the risk of a following collapse of asset prices (see also BIS 2010). Rajan (2005) had already developed this idea in the "search for yield" approach. How can the challenge stemming from low interest rates, the development of money and credit and risks for asset price imbalances be reconciled with the philosophy of inflation targeting? Just by ignoring the fundamentals of this approach and applying "good judgement”?

Taking asset price developments into account is a challenge for any monetary policy strategy. Monetary factors are and will remain an alien element in inflation targeting. However, they were important in the ECB's monetary policy strategy. "Money” was given a prominent role from the beginning. In contrast to what is still used to discredit (?) this strategy by calling it monetary targeting (Clarida 2010, p. 2) the ECB has explicitly rejected this approach already before the start. ${ }^{7}$ Monetary analysis and economic analysis are the "two pillars" of the ECB's strategy which are connected via cross-checking into an integrated approach (see e.g. Beck/Wieland 2008).

As intended from the beginning monetary analysis was deepened and broadened over time (Issing 2005). The analysis of developments of different monetary aggregates, components, and their counterpart with monitoring all aspects of credit is a huge challenge, but delivers also important insights (see Papademos/Stark 2010; ECB 2010 b). ${ }^{8}$

Important as money and credit are in the context of asset price developments the fundamental question is which role these factors should play in a monetary policy strategy designed to deliver price stability. As mentioned before, neglect of money and credit was a common factor not only in academic research (see e.g. Woodford 2003; Eggertson/Woodford 2003) but also in a number of central banks (see e.g. the impressive work by Meltzer, 2009). Though being fully aware of all the problems demonstrated over time by a lot of research I never understood how monetary policy could ignore "money” and how the central bank should not care about “money creation”. There is of course a complex transmission mechanism from central bank money to narrow and even more to broad monetary aggregates and credit - and also the reverse direction! - to nominal GDP, the real economy and prices. Even the definition

\footnotetext{
${ }^{7}$ See e.g. the headline "Deciding against a monetary target” in Issing 2008, p. 93; Issing et al. 2001).

${ }^{8}$ An interesting approach is Shin/Shin (2011) which distinguishes monetary aggregates on the criterion of the money holding sector and differentiate between bank and market dominated financial systems.
} 
of what is "money" is anything but easy and measuring "credit" is not simple either. Here is not the place to try even a modest assessment of the result of libraries of research. But, I would like to make just two points.

First of all, there is hardly any dissent that in the long run inflation is a monetary phenomenon. Lucas (1996) refers to the overwhelming empirical evidence and sees as a consequence that the relationship between monetary growth and inflation "needs to be the central feature of any monetary or macroeconomic theory that claims empirical seriousness”. Or as M. King (2002) phrased a headline: "No Money, no Inflation”.

So, the question cannot be if, but how central banks should take this relationship into account when assessing risks to price stability and making monetary policy decisions. With its monetary policy strategy the ECB has taken up this challenge. It has never claimed that its approach would be the final answer. However, it seems strange to me that critique was directed mainly at giving monetary factors a role at all - without presenting an alternative that would meet this challenge in a better way. Admittedly, the strategy could not be formulated in an elegant model like (however, only initially) inflation targeting, and from the beginning included an element of judgement. As a consequence it lacked the "elegance” which made it obviously not attractive for academics.

A. Lamfalussy (2005) has an interesting comment: "In such a situation adopting an eclectic monetary policy strategy is an act of intellectual and professional honesty, for which the ECB deserves praise, rather than blame. At the same time, such a strategy deprives the ECB's policy-makers of the possibility of enjoying what we would call in French a 'confort intellectuel’ “. Blanchard (2007) gave a warning: “...I worry that we have been lulled- or we have lulled ourselves- into a sense of complacency which is not warranted. There are still many issues we do not understand, and these may come back to bite us with a vengeance in the future"(see also Orphanides 2009). The "future" was waiting just around the corner, and is this experience not a strong argument for "robustness"?

The recent financial crisis which is also a crisis of mainstream macroeconomics should be an argument for honesty or humility also for other approaches than that of the ECB. 
Second, monetary analysis in the ECB's monetary strategy identifies longer-term risks to price stability which economic analysis and the usual forecasts cannot deliver. Monitoring monetary developments therefore provides the basis for a medium-term orientation which pays tribute to the substantial time-lags and protects the central bank from the risk of destabilizing “activism” (see Issing 2002). Friedman`s (1968 p.12) warning is today as relevant as ever: "The first and most important lesson that history teaches about what monetary policy can do - and it is a lesson of the most profound importance - is that monetary policy can prevent money from being a major source of macroeconomic disturbance”.

At the same time monitoring money and credit can create a "barrier" against major policy mistakes and following macroeconomic disaster (Christiano/Rostagno 2001). The monetary pillar warns on rising imbalances in the monetary sector which are in general correlated with financial imbalances and helps the central bank maintain a steady hand (Fahr et al. 2010). "Leaning against the wind" in both directions is therefore an implicit consequence whereas focussing on short-term inflation developments may exaggerate the boom bust behaviour driven by expectations of productivity elements.

Interestingly, monetary analysis may also overcome information problems in identifying developments in the real sector (see e.g. Gerberding et al. 2010).

\section{More Lessons?}

There are a number of other important issues which are discussed under the headline "Lessons from the Crisis" The challenge from the "zero bound" has been discussed since long. Central banks in the meantime have demonstrated that monetary policy has efficient tools also in such an environment. Another approach to deal with this problem is to raise the inflation target to get more room for manoeuvre to reduce interest rates in case of major shocks. Blanchard et al. (2010) argue in favour of a target of $4 \%$ because the zero nominal interest rate bound has proven too costly in the context of the recent crisis.

To avoid the costs of higher inflation they suggest changes in the tax system and issuance of indexed bonds. Evidence from a large bulk of studies conducted during times of high inflation does not suggest that this is either easy to implement or efficient. However, there is another dimension of economic and social costs which go far beyond those calculations. This is the 
loss of credibility of central banks having successfully convinced the public and markets that low and stable inflation is essential (see e.g. ECB 2001). By raising the inflation target, well guided inflation expectations would loose their anchor. Why should people believe that $4 \%$ is now the "final" limit? What arguments could be used tomorrow in favour of another increase? It is hard to imagine that central banks could stabilise inflation around the new target. And, even if they were successful, higher inflation volatility would be unavoidable.

In this context it has to be mentioned that defining "price stability" as an annual inflation rate of not more than $2 \%$ is already not easy to explain to the general public. Such a number is already a compromise and violates in some respect principles of stable money. It is not so long ago that "zero inflation” was debated, and there is still research on the optimal inflation rate which results in rates below $2 \% .{ }^{9}$ How could a central bank like the ECB with a constitutional mandate of maintaining price stability argue that this is consistent with $4 \%$ annual inflation?

When the ECB evaluated its monetary policy strategy, it also studied the risk of the zero bound and the appropriate definition of price stability (Issing 2003). As a result strong arguments against an "upper bound” of more than $2 \%$ were presented.

A fundamental objection against the consideration to raise the target in order to have more room for reducing central banks interest rates in case of a major stock is the fact that the "need" for this flexibility is not independent from the preceding monetary policy. Raising the target with all the consequences mentioned would lead to stronger growth of money and credit thereby contributing to if not causing monetary imbalances and asset price booms. According to the logic of the argument the following collapse of asset prices might implicitly deliver new arguments for further raising the inflation target. ${ }^{10}$

As a consequence it becomes obvious that the idea of raising the inflation target has to be seen in the context and as a consequence of an activist monetary policy with a strong commitment to steer output and employment. This leads to the question of the mandate of the central bank which is also discussed as a consequence of the crisis. No central bank will ignore the situation of the real economy and the impact of its policy. A central bank will take those considerations best into account by conducting a medium-term oriented monetary policy to maintain price stability, anchoring inflation expectations, avoiding fine-tuning. This is in line

\footnotetext{
${ }^{9}$ Schmitt-Grohé and Uribe (2010) e.g. discuss optimal inflation rates of at most zero percent a year.

${ }^{10}$ Blanchard et al. also mention shocks like terrorist attacks. But, is this a challenge for the zero bound?
} 
with a single mandate to maintain price stability. For a central bank with a dual mandate it might be very difficult to explain the limits of what it can do - or rather not do - especially in the case of structural unemployment. The most likely outcome of a dual mandate will be that the central bank is trying to achieve one objective at a time (Meltzer 2009). This approach can hardly be reconciled with a monetary policy in which monitoring money and credit is an essential element of a medium-term orientation.

Central banks on the basis of a formal mandate also for financial stability or as an informal obligation as a consequence of the recent crisis will be confronted with a tremendous challenge. For a central bank with a medium-term orientation taking developments of money and credit into account while focussing on maintaining price stability this implies a strong presumption that monetary policy itself will not cause major financial imbalances, but contribute also to financial stability. This is not at all an argument against macroprudential supervision and regulation. How responsibility in this field should best be allocated is a difficult question.

Independence of the central bank would be hard to defend if it has also the competence to deal with individual financial institutions up to the question if such a firm should be closed. The crisis management and some forms of unorthodox measures or quantitative easing have also raised concerns about the relation of the central bank with the fiscal authority.

The world of central banking will not be the same as it was before (see e.g. Goodhart 2010). However, this is no reason to ignore the principles of sound monetary policy which were developed over time. Progress in policy comes by crises, research has to work on the scientific fundament for conducting good policies. Both, central banks and research have to take "lessons" - hopefully the right ones. 


\section{Bibliography}

Adrian,T. and Shin, H.S. (2009), Prices and Quantities in the Monetary Policy Transmission Mechanism, International Journal of Central Banking, December.

Alessi, Lucia and Detken, Carsten (2009), Real Time Early Warning Indicators for costly Asset Price Boom/Bust Cycles: a Role for Global Liquidity, ECB Working Paper No. 1039.

Bank for International Settlements (2010), 80 ${ }^{\text {th }}$ Annual Report, Basel.

Bank of England (2009), The Role of Macroprudential Policy, Discussion Paper, November.

Bean, Charles (2010), Monetary Policy after the Fall, Paper presented at the Federal Reserve Bank of Kansas City Annual Conference, Jackson Hole, August 28.

Beck, Günter and Wieland, Volker (2008), Central Bank Misperceptions and the Role of Money in Interest Rate Rules, Journal of Monetary Economics.

Blanchard, Olivier (2007), Central Banking: Is Science Replacing Art?, in: ECB, ed. Monetary Policy, A Journey from Theory to Practice, Frankfurt.

Blanchard, Olivier; Dell’Ariccia, Giovanni; Mauro, Paolo (2010), Rethinking Macroeconomic Policy, Journal of Money, Credit and Banking, 42, 6, Suppl.

Blinder, Alan S. (2010), How Central should the Central Bank be? Journal of Economic Literature, March.

Blinder, Alan S. and Reis, R. (2005), Economic Performance in the Greenspan Era: The Evolution of Events and Ideas, in: The Federal Reserve Bank of Kansas City (ed.), The Greenspan Era: Lessons for the Future.

Borio, Claudio E. V. and Filardo, A. (2007), Globalisation and Inflation, New Cross-Country Evidence on the Global Determinants of Domestic Inflation, BIS Working Paper No. 227, Basel.

Borio, Claudio E. V. and Lowe, P. (2004), Securing Sustainable Price Stability: Should Credit come in from the Wilderness?, BIS Working Paper No 157, Basel.

Borio, Claudio E. V. and Lowe, P. (2002), Asset Prices, Financial and Monetary Stability: Exploring the Nexus, BIS Working Paper No. 114, Basel.

Borio, Claudio E.V. and Zhu, Haibin (2008), Capital Regulation, Risk-Taking and Monetary Policy: A Missing Link in the Transmission Mechanism, BIS Working Paper No. 268. 
Buiter, Willem H. (2008), Central Banks and Financial Crises, in: The Federal Reserve Bank of Kansas City (ed.), Maintaining Stability in a Changing Financial System.

Christiano, L. J. and Rostagno, Massimo (2001), Money Growth Monitoring and the Taylor Rule, NBER Working Paper No. 8539.

Cicarelli, M. and Mojon, B. (2010), Global Inflation, Review of Economics and Statistics.

Clarida, Richard H. (2010), What has - and has not - been learned about Monetary Policy in a Low Inflation Environment? A Review of the 2000s, October 12.

Curdia, Vasco and Woodford, Michael. 2010, Credit Spreads and Monetary Policy, Journal of Money, Credit and Banking, Blackwell Publishing, vol. 42(s1), pages 3-35, 09.

Detken, Carsten and Smets, Frank (2004), Asset Price Booms and Monetary Policy, in: H. Siebert (ed.), Macroeconomic Policies in the World Economy, Berlin.

Eggertson, G. and Woodford, M. (2003), The Zero Bound on Interest Rates and Optimal Monetary Policy, Brookings Papers on Economic Activity.

European Central Bank (2000), The Two Pillars of the ECB`s Monetary Policy Strategy, Monthly Bulletin, November.

European Central Bank (2005), Asset Price Bubbles and Monetary Policy, Monthly Bulletin, April.

European Central Bank (2010a), Asset Price Bubbles and Monetary Policy Revisited, Monthly Bulletin, November.

European Central Bank (2010b), Enhancing Monetary Analysis, Monthly Bulletin, November.

Fahr, Stephan; Motto, Roberto; Rostagno, Massimo; Smets, Frank; Tristani, Oreste (2010), A Monetary Policy Strategy in Good and Bad Times. Lessons from the Recent Past, Sixth ECB Central Banking Conference, Frankfurt, November 18-19.

Fisher, Irvin (1932), Booms and Depression, New York.

Friedman, Milton and Schwartz, Anna J. (1963), A Monetary History of the United States, 1867-1960, Princeton.

Gerberding, Christina; Scharnagel, Michael; Seitz, Franz (2010), Should Monetary Policy respond to Money Growth? New Results for the Euro Area, International Finance, Winter. 
Gerdesmeier, Dieter; Reimers, H.-E.; Roffia, B. (2009), Asset Price Misalignements and the Role of Money and Credit, ECB Working Paper No. 1068.

Goodhart, Charles A.E. (2010), The Changing Role of Central Banks.

Greenspan, Alan (2002), Opening Remarks, in: The Federal Reserve Bank of Kansas City (ed.), Rethinking Stabilization Policy.

Greenspan, Alan (2005), Opening Remarks, in: The Federal Reserve Bank of Kansas City (ed.), The Greenspan Era. Lessons for the Future.

Hayek, Friedrich August (1933), Monetary Theory and the Trade Cycle, London.

Herrero, Alicia Garcia et al. (eds.), Why Price Stability?, First ECB Central Banking Conference, ECB, Frankfurt.

IMF (2010), Central Banking Lessons from the Crisis, May 27.

Issing, Otmar (2002), Monetary Policy in a Changing Economic Environment, in: The Federal Reserve Bank of Kansas City (ed.), Rethinking Stabilization Policy.

Issing, Otmar, (ed.), (2003a), Background Studies for the ECB's Evaluation of its Monetary Policy Strategy, ECB, Frankfurt.

Issing, Otmar (2003b), Monetary and Financial Stability: is there a Trade-off?, BIS Paper No. 18 , September.

Issing, Otmar (2004), Inflation Targeting: A view from the ECB, Federal Reserve Bank of St.Louis, Review, July/August.

Issing, Otmar (2005), The Monetary Pillar of the ECB, Conference “The ECB and Its Watchers VII”, Frankfurt, June 3.

Issing, Otmar (2008), The Birth of the Euro, Cambridge.

Issing, Otmar (2009), Asset Prices and Monetary Policy, The Cato Journal, Winter.

Issing Otmar (2010), The Development of Monetary Policy in the $20^{\text {th }}$ Century - Some Reflections, Revue bancaire et financière, June.

Issing, Otmar; Gaspar, Vitor; Angeloni, Ignazio; Tristani, Oreste (2001), Monetary Policy in the Euro Area, Cambridge.

King, Mervyn A. (2002), No Money, no Inflation, Bank of England, Quaterly Bulletin. 
Kohn, Donald L. (2007), Monetary Policy and Asset Prices, in: ECB ed., Monetary Policy, A Journey from Theory to Practice, Frankfurt.

Lamfalussy, Alexandre (2005), Statement, in: ECB (ed.), The Single Currency and Implications for Governance.

Lucas, Robert E. (1996), Monetary Neutrality, Journal of Political Economy, 104(3).

Lucas, Robert E. (2007), Central Banking: Is Science Replacing Art? in: ECB ed., Monetary Policy, A Journey from Theory to Practice, Frankfurt.

Meltzer, Allan H. (2009), A History of the Federal Reserve, Vol. 2, Book 2, Chicago.

Mishkin, Frederic S. (2007), Will Monetary Policy become more of a Science? NBER Working Paper 13566.

Mishkin, Frederic S. (2010), Monetary Policy Strategy. Lessons from the Crisis, Prepared for the ECB Central Banking Conference, Frankfurt, November 18-19.

Orphanides, Athanasios and Wieland, Volker (2008), Economic Projections and Rules of Thumb for Monetary Policy, Federal Reserve Bank of St.Louis, Review, July/August.

Orphanides, Athanasios (2009), What have Economists learned about Monetary Policy over the Past Fifty years? Discussion, in: Deutsche Bundesbank, ed., Monetary Policy over Fifty Years, Frankfurt.

Papademos, Lucas D. (2009), The “Great Crisis” and Monetary Policy: Lessons and Changes, in: Oesterreichische Nationalbank, $37^{\text {th }}$ Economic Conference.

Papademos, Lucas D. and Stark, Jürgen (eds.) (2010), Enhancing Monetary Analysis, Frankfurt.

Rajan, Raghuram G. (2005), Has Financial Development Made the World Riskier?, The Federal Reserve Bank of Kansas City (ed.), The Greenspan Era.

Rüffer, R. and Stracca, L. (2007), What is Global Excess Liquidity, and does it matter?, ECB Working Paper No. 696.

Shin, Hyun S. and Shin, Kwanho (2011), Procyclicality and Monetary Aggregates, NBER Working Paper 16836, February.

Schmitt-Grohé, Stephanie and Uribe, Martin (2010), The Optimal Rate of Inflation, CEPR Discussion Paper No. 7864, June. 
Sousa, J. and Zaghini, A. (2004), Monetary Policy Shocks in the Euro Area and Global Liquidity Spillovers, ECB Working Paper No. 309.

Svensson, Lars E. O. (2005), Monetary Policy with Judgement: Forecast Targeting, International Journal of Central Banking.

Svensson, Lars E. O. (2009), Flexible Inflation Targeting - Lessons from the Financial Crisis, The Netherlands Bank, Amsterdam, September 21.

Taylor, John B. (2007), Housing and Monetary Policy, in: The Federal Reserve Bank of Kansas City (ed.), Housing, Housing Finance, and Monetary Policy.

Walsh, Carl E. (2009), Inflation Targeting: What have we learned?, International Finance, Summer.

White, William R. (2009), Should Monetary Policy “Lean or Clean”?, Center for Financial Studies, May 27. 